\title{
Investigation of Healing Effects of Afyon Region Thermal Spring Water on Experimentally-Induced Gastritis in Mice
}

\section{ELITOK Bülent ${ }^{1}$, ULUSOY Yavuz ${ }^{2}$, KİLINÇ Bahadir ${ }^{2}$, EMEKSIZ Mehmet Ali ${ }^{3}$}

1. Afyon Kocatepe University, Faculty of Veterinary Medicine, 2. Ministry of Agriculture and Forestry, Veterinary Control Central Research Institute, Pathology Laboratory, Ankara/ Turkey

3. Master Student/Private Veterinarian, 3400-İstanbul/Turkey Corresponding author: ELITOK Bülent, Email: elitok1969@hotmail.com, ORCID: https:/ /orcid. org/ 0000-0003-3336-4479

\begin{abstract}
In this study, 40 Albino mice were induced with ethyl alcohol to form of gastritis. In the treatment stage, control group mice were given tap water, while study group mice were given fresh water of Süreyya I hot spring. Clinical, hematological, biochemical, blood gases measurements and histopathological examinations of the gastric tissue were performed on the 1st, 7th, 14th and 21th days after the initiation of the treatment. At the end of the study, no significant difference was found between the groups in terms of body temperature ( $p>0.05)$, whereas heart and respiratory frequencies were significantly higher in the study group animals $(\mathrm{p}<0.05)$. Although mean WBC, NOTR, MON, EOS and MCV decreased significantly in both groups $(\mathrm{p}<0.05)$, it was found that the mean of these parameters were more significant in SG at all measurement times $(\mathrm{p}<0.05)$. It was determined that TP, ALB and GLU levels increased in SG contrast to CG, and statistically significant decreases in AST, ALT, CK, ALP, LDH, UREA, CREA and $\mathrm{IgG}$ levels after the treatment. Additionally, $\mathrm{pH}$, partial $\mathrm{CO}_{2}$ pressure, base deficit, bicarbonate, $\mathrm{Ca}$ and $\mathrm{K}$ levels decreased after gastritis procedure, whereas lactate, $\mathrm{Na}$ and $\mathrm{Cl}$ levels increased. Consequently, the clinical, hematological, blood biochemical parameters, blood gases and histopathological findings were evaluated as a whole, it was concluded that Süreyya I hot spring water was very successful in the treatment of gastritis.
\end{abstract}

Key words: Afyonkarahisar, balneotherapy, gastritis, mice, treatment,

\section{Introduction}

Gastritis is a general term used to describe the inflammation of the gastric mucosa, and secondary developing acute or chronic vomiting syndrome in human and some kind of animals (1). Causes include malnutrition, drug or toxin intake, systemic diseases, endoparasitism, bacterial (Helicobacter pylori) or viral infections $(2,3)$.

Balneotherapy may be an alternative chooice for treating gastritis (4). So, there are important studies reporting that hot spring waters increase gastric blood flow and improve gastritis $(4,5)$. Some previous studies have found that continuous use of bicarbonate mineral waters in appropriate doses is highly effective in the treatment of gastrointestinal disorders such as dyspepsia and motility disorders (6). In another study (7), the healing effects of spa waters are mentioned in gallstone cases that can cause gastritis problems, and it has been reported that the gastric mucosa, which is frequently shaped during the disease, provides very useful results in the correction of pathology in chronic gastritis cases. In addition, it has been reported that spa waters can be used successfully in hyperchloremic and hypochloremic cases by showing biphasic effect $(8,9)$.

This study was carried out to reveal the effectiveness of Süreyya I hot spring water in Afyonkarahisar, which has a rich mineral composition, in the treatment of gastritis.

\section{Material and Methods}

The experimental part of this study was carried out in Afyon Kocatepe University Experimental Animals Application and Research Center, in accordance with the Directive of Afyon Kocatepe University Experimental Animals Ethics Committee (AKUHADYEK) with the report number 58-18, and supported by Afyon Kocatepe University Scientific Research Projects Board (AKÜBAPK) as Master's Thesis with Project No. 18.SAĞ.BİL.13.

\section{Animal Material}

In this study, totally 40 adult Albino rats of same age at birth age were used. The animals were kept in Afyon Kocatepe University Experimental Animals Application and Research Center by dividing a total of 12-12 days, day and night. Throughout the study, mice were allowed to access ad libitum food. 


\section{Creating Experimental Gastritis}

Before applying the gastritis procedure, 4 of 40 mice were exed for collecting blood samples. Remaining mice $(\mathrm{n}=36)$ was given $8 \mathrm{~mL} / \mathrm{kg}$ of $50 \%$ ethanol by orogastric tube, and gastritis was created (Swarnakar et al., 2017). After 3 hours after the gastritis procedure was performed in all the animals, 4 mice also exed for collecting samples, and the remaining 32 mice were divided equally and randomly into 2 groups for the 21-day treatment period as follows:

1 Control Group (CG): Totally 16 mice created gastritis served as CG, andtap water was given twice a day with an orogastric tube at the dose of $1 \mathrm{~L} / 33 \mathrm{~kg}$ body weight (bw). In addition, tap water was added to the drinkers of this group animals, and they were provided access to water and food as ad libitum. All the mice in this group were bathed with fresh tap water at $35 \pm 2{ }^{\circ} \mathrm{C}$ for 15 minutes at the same time once a day for 21 day.

2. Study Group (SG): Remaning 16 mice created gastritis served as SG, and $1 \mathrm{~L} / 33 \mathrm{~kg}$ bw Süreyya I hot spring water was given twice a day with an orogastric tube at the dose of $1 \mathrm{~L} / 33 \mathrm{~kg}$ bw. In addition, Süreyya I hot spring water was added to the drinkers of this group, and they were provided access to water and food as ad libitum. All the animals in SG were bathed with fresh hot spring water at $35 \pm 2{ }^{\circ} \mathrm{C}$ for 15 minutes at the same time once a day for 21 day.

Süreyya I Hot Spring Water, used for the purpose of treatment in this study, has a total mineral content of $4046.8 \mathrm{~g} / \mathrm{L}$, and is in the thermomineral water group with sodium bicarbonate, carbon dioxide, magnesium, calcium, fluoride and silicon.

\section{Methods}

\section{Clinical Examinations}

Body temperatures $(T)$, respiratory rates $(R)$ and heart frequencies $(\mathrm{P})$ were measured in all animals used in the study, and the results were recorded for statistical comparisons.

\section{Collecting Blood and Tissue Samples}

During the collection of blood and stomach tissue samples, 4 mice were randomly selected and euthanasied under ketamine $(100 \mathrm{mg} / \mathrm{kg}) / x y l a z i n e ~(10 \quad \mathrm{mg} / \mathrm{kg})$ anesthesia on the 1st, 7th, 14th and 21st days of treatment. and stomach tissue samples were taken (10). Tissue samples were stored at $10 \%$ formol and $+4{ }^{\circ} \mathrm{C}$ for histopathological examinations and sent to the Etlik Veterinary Research and Application Institute Pathology Laboratory.

\section{Hematological Examinations}

In hematological examinations; RBC, WBC, HCT, HB, MHC, MCHC, LENF, NOTR, EOS, MON and BAS values were measured with Chemray Brand blood count device using commercial test kits.

\section{Blood Biochemical Examinations}

In blood biochemical examinations; AST, ALT, CK, LP, TP, ALB, UREA, GLU and CREA values were measured on the Cobas Integra 400 Plus Roche Brand (Roche Diagnostics $\mathrm{GmbH}$, Germany) analyzer using test kits. IgG levels were measured using Chmewell Elisa Reader (ChemWell Chromate 4300 Elisa Reader, Awareness Technology, Inc. Martin Hwy. Palm City, USA) using commerical Elisa kits (Sunred Biological Technology Company Co. Shangai/China).

\section{Blood Gases Measurements}

Blood samples required for blood gases measurements were prepared as $1 \mathrm{ml}$ of blood/500 IU of liquid heparin and obtained with the help of special injectors. In the samples taken, the measurement of blood gases was carried out in less than $<3$ hours. In these samples; partial carbon dioxide pressure $\left(\mathrm{PCO}_{2}\right), \mathrm{pH}$, total carbon dioxide concentration $(\mathrm{TCO} 2)$, partial oxygen pressure $\left(\mathrm{PO}_{2}\right)$, bicarbonate $\left(\mathrm{HCO}_{3}^{-}\right)$, base deficit $(\mathrm{BE})$, potassium $\left(\mathrm{K}^{+}\right)$, sodium $\left(\mathrm{Na}^{+}\right)$, chlorine $\left(\mathrm{CI}^{-}\right)$, calcium $\left(\mathrm{Ca}^{++}\right)$values were made using a portable blood gas analyzer (Edan İ15 Blood Gases Instrument-Veterinary) using commercial cartridges.

\section{Histopathology Examinations}

After anesthesia application, 4 mice were exed and stomach samples were taken according to method described by Suckow et al. (10). Tissue samples were sent to the laboratory in a $10 \%$ formol, 5 micron thick sections were taken from the stomach samples and stained with hematoxylin-eosin dye and examined under a light microscope.

\section{Statistical Analyses}

Statistical calculations were made using variance analysis (ANOVA), and intra-group differences were detected with Duncan test. These analyzes were calculated using Windows compatible SPSS 18.1 (Inc., Chicago, II, USA) package program, data were determined as mean \pm standard error and $\mathrm{p}<0.05$ was considered important.

\section{Results}

On the 21st day of the treatment, the mean bw (29.6 g) of CG mice was found to be statistically significantly higher $(\mathrm{p}<0.05)$ than the bw mean of SG mice (28.5 g).

\section{Clinical Findings}

Clinical findings of animals are shown in Table 1. When Table 1 is examined; While there is no significant difference in terms of $\mathrm{T}$ with the occurrence of gastritis $(p>0.05)$, while significant differences $(p<0.05)$ were seen in terms of mean $P$ and $\mathrm{R}$, and, the most important increases in intergroup and intragroup comparisons were determined in SG animals, and the difference is statistically significant $(\mathrm{p}<0.05)$. 


\section{Hematological Findings}

The hematological examination findings of the animals are shown in Table 2. When Table 2 is examined; WBC, NOTR, MON, EOS and MCV levels increased statistically significantly $(p<0.05)$ after gastritis formation, while RBC, HG, HCT, LENF, PLT, MCH and MCHC levels decreased significantly $(p<0.05)$. With the transition to the treatment period, on the contrary, an increase in mean RBC, HG, HCT, LENF, PLT, MCH and MCHC, whereas WBC, NOTR, MON, EOS and $\mathrm{MCV}$ levels decreased in both groups. However, occured changes were more significant in SG animals $(\mathrm{p}<0.05)$.

\section{Blood Biochemical Findings}

The averages of the blood biochemical parameters measured in the present study are shown in Table 3. When this table is examined; It was found that the mean of AST, ALT, CK, ALP, LDH, UREA, CREA and $\mathrm{IgG}$ increased significantly $(\mathrm{p}<0.05)$ after gastritis formation, while mean TP, ALB and GLU decreased significantly $(\mathrm{p}<0.05)$. With the initiation of treatment, it was found that mean TP, ALB and GLU increased in both groups, whereas AST, ALT, CK, ALP, LDH, UREA, CREA and IgG averages decreased, but these changes were statistically more significant in SG animals $(\mathrm{p}<0.05)$.

\section{Blood Gases Analyses Findings}

The blood gases analyses results we obtained in the study are presented in Table 4 . When this table is examined; it was found that $\mathrm{pH}, \mathrm{pCO}_{2}, \mathrm{BE}, \mathrm{HCO}_{3}$, $\mathrm{Ca}$ and $\mathrm{K}$ levels decreased after gastritis formation, while LACT, $\mathrm{Na}$ and $\mathrm{Cl}$ levels increased. With the transition to the treatment period, it was observed that $\mathrm{pH}, \mathrm{pCO}_{2}, \mathrm{BE}, \mathrm{HCO}_{3}, \mathrm{Ca}$ and $\mathrm{K}$ levels increased, while LAKT, $\mathrm{Na}$ and $\mathrm{Cl}$ levels decreased and reached normal limits. Improvements in these parameters were statistically more significant in SG animals $(\mathrm{p}<0.05)$ compared to CG.

\section{Histopathological Findings}

In histopathological examinations; severe inflammation characterized by mononuclear cell infiltrations in gastric tissue samples taken after gastritis formation was remarkable (Figure 1). On the other hand, it was observed that the improvement in the tissue samples of the animals treated with hot spring water was notable (Figure 2), while histopathological findings of gastritis continued in the tissue samples comes from CG animals (Figure 3).

\section{Discussion}

Although, gastritis is most common problem of human and animals, we can not find any literatures about balneotherapy in domestic animals with gastritis. Hence, our findings discussed with findings obtained from laboratory animals and human being.

In our study, it was found that weight loss in SG animals was higher than CG mice with treatment. This finding was found to be compatible with studies reporting that balneotherapy practices caused weight loss (11). On the other hand, it was observed that $\mathrm{P}$ and $\mathrm{R}$ frequencies increased significantly in $\mathrm{SG}$ animals compared to $\mathrm{CG}$ following treatment period. These findings were found to be compatible with the findings previously declared by some researchers (12-14), who reported that balneotherapy practices caused the sympathetic nervous system to be stimulated and increased blood pressure, heart and respiratory frequency.

In our study, it was determined that WBC, LENF and EOS levels decreased in SG animals which were given Süreyya I hot spring water. These findings are similar to the findings reported by some researchers $(11,15)$ who claimed that hot water suppresses $\mathrm{T}$ lymphocytes and suppresses cytokine production by suppressing the immune system. However, some researchers (16) declared that low temperature stimulates the somatotrope hormone and causes leukocyte increase.

One of the most important complications of alcohol intake is chronic inflammation $(17,18)$. Alcohol destroys the barrier cases in the intestine and contributes to the access of the bacterial lipopolysaccharides to the liver through the portal vein (19). Neutrophilic infiltration is also frequent phenomenon as a result of long-term alcohol consumption (20). In this study, the high detection of NOTR levels after ethanol administration is in parallel with these studies. In our study, lower WBC and NOTR counts were determined in SG animals following treatment period. It is thought that Sureyya I hot spring water is rich in magnesium might also have an effect on this condition. So, it has been reported that the deficiency of magnesium also causes an increase in inflamation due to leukocyte and macrophage activation and overproduction of free radicals (21).

In this study, the levels for AST, ALT, GGT, ALP, LDH, GLU, UREA, CREA, IgG investigated were found to be high after the formation of gastritis, while TP and ALB were low. With the onset of treatment, it was observed that an improvement in terms of the mentioned parameters was observed in the progressive time periods in SG mice treated with hot spring water compared to $C G$ mice. Our these findings consistent with the findings reported by some researchers $(21,22)$ who reported that treatment with mineral water prevents the formation of metabolic syndrome in rats with metabolic syndrome, and decreases in the levels of AST, ALT, ALP, UREA, 
CREA, and causes increases in TP and ALB concentrations.

In the current study, after gastritis formation by giving ethanol, it was determined that there were significant differences in lipid profile in the animals, and compared to before the study, levels for TG, LDL, and TCHOL increased, while HDL cholesterol averages decreased following gastritis formation. On the other hand, with the transition to the treatment period, it was found that significant improvements in lipid profile in SG mice when compared to CG animals, and the best results were obtained in the last week of the study. These data we obtained were in line with finding reported by some researchers $(22,23)$ who claimed that the use of thermal waters had significant regulatory effects on serum lipids. Murakami et al. (6), continuous use of bicarbonate mineral water in appropriate doses had been found to be very effective in the treatment of gastrointestinal disorders such as dyspepsia and motility disorders. As a matter of fact, bicarbonate waters have been shown to have important healing effects in chronic gastric cases and increase antioxidant capacity by improving lipid peroxidation-antioxidant defense system and regulation of lipid metabolism (24).

There are many studies reporting that balneotherapy can have important effects in reducing blood glucose levels (25). It has been reported that the mechanism of action of balneotherapy on the subject in this regard may be related to the ability to regulate the distribution of nutrients absorbed from the intestines with high blood glucose (26). Similar findings were obtained in this study, and GLU levels were determined lower ranges than those of CG animals.

In the literature scans we have done, we have not found any study on the change of blood gases after gastritis and balneotherapy after gastritis. For this reason, the data we obtained in this study is the first written data and the first study obtained in this field. Intense alcohol consumption is associated with metabolic acidosis (27), it is observed that blood $\mathrm{pH}$, $\mathrm{PCO}_{2}, \mathrm{HCO}_{3}$ levels decrease and LACT levels increase (28). In our current study, although similar findings were detected in animals that were given alcohol, after the treatment with Süreyya I hot spring water in SG animals, a reverse situation was formed in these parameters and towards the last weeks of the treatment, it was determined that the high parameters of lactic acidosis-related metabolic acidosis table improved. It has been identified. Similar findings have been reported in another study $(8,29)$ who reported that treatment with spa waters significantly reduced LACT concentrations, and treatment with hot spring water can be used successfully in hyperchloraemic and hypochloremic cases.

In metabolic acidose, high levels of $\mathrm{Na}$ and $\mathrm{Cl}$ levels and low levels of $\mathrm{Ca}$ and $\mathrm{K}$ have been reported (27). In our current study, it was observed that $\mathrm{Na}$ and $\mathrm{Cl}$ levels decreased after treatment in SG animals, while $\mathrm{Ca}$ and $\mathrm{K}$ levels increased. These findings show that Süreyya I spa spring water is highly effective in the improvement of metabolic acidose findings.

In our current study, it was observed that microvesicular style, sometimes both in macro and microvesicular mix, and severe inflammation was characterized by mononuclear cell infiltrations accompanied by parenchymal degeneration and sometimes necrosis foci in tissue samples (Figure 1). These findings were consistent with studies $(2,30)$ reporting that alcohol use had similar histopathological effects on stomach tissue. In histopathological examinations of tissue samples taken in the last week of treatment; SG animals treated with hot spring water showed a clear histopathological improvement (Figure 2), while gastritis was continuing in CG mice (Figure 3).

\section{Conclusions}

As a result; findings obtained from this study were evaluated as a whole; it was concluded that treatment with Süreyya I hot spring water was very successful in in treatment of mice with gastritis. Hence, it can be used alone or in combination with classical medical treatment in the treatment of gastritis.

\section{Declaration of conflict of interests/Conflict of Interest Statement}

The authors declare that there is no conflict of interest regarding the publication of this article.

\section{Informed consent}

Informed consent was obtained from all patients included in this study.

\section{Acknowledgement}

Special thanks to Mr. Suayp Demirel for his supporting during study.

\section{References}

1. Yoshikawa T, Yasuda M, Ueda S. Vitamin E in gastric mucosal injury induced by ischemia-reperfusion. Am J Clin Nutr 1991; 53:210-4.

2. Wolf G. Effect of alcohol on the stomach. Gastroenterol J. 1989; 49(2):45-9. 
10. Suckow MA, Danneman P, Brayton C. The laboratory mouse. CRC Press LLC, USA, 2001.

3. Malfertheiner P, Chasn Fk, Mccoll KE. Peptic ulcer disease. Lancet. 2009; 374:1449-61.

4. Etani R, Kataoka T, Kanzaki K, Sakoda A, Tanaka H. et al. Protective effects of hot spring water drinking and radon inhalation on ethanol-induced gastric mucosal injury in mice, Journal of Radiation Research. 2017; 58(5): 614-625.

5. Gosink, TA, Baskaran M, Holleman DF. Radon in the human body from drinking water. Health Phys. 1990; 59:919-24.

6. Murakami S, Goto Y, Ito K. The Consumption of Bicarbonate Rich Mineral Water Improves Glycemic Control. Evidence-Based Complementary and Alternative Medicine. 2015; Article ID 824395.

7. Gorbunov ALU. Treatment of patients with cholelithiasis and concomitant gastritis using sodium-calcium sulfate mineral water. Vopr Kurortol Fizioter Lech Fiz Kult. 2010; (6):21-3.

8. Chaban AG, Lysiuk AD, Chernobrovyi VN, Kuchuk AP. The therapeutic efficacy of a sodium chloride mineral water in chronic gastritis patients with secretory insufficiency. Vopr Kurortol Fizioter Lech Fiz Kult. 1990; (5):17-9.

9. Elitok, B. Kaplıcaların Mineral Mucizesi. Hancıoğlu Ofset, Afyonkarahisar, 2011.

11. Lange $U$, Muller-Ladner $U$, Schmidt KL. Balneotherapy in rheumatic diseases--an overview of novel and known aspects. Rheumatol Int. 2006; 26(6): 497-9.

12. Agishi Y. Endocrine and metabolic aspects of balneotherapy. Biometeorology. 1985; 10(29):89-103.

13. Agishi, Y. (1995). Hot springs and the physiological functions of humans. Asian Med J, 38:115-124.

14. Greco-Otto P, Bond S, Sides R, Kwong GPS, Bayly W, et al. Workload of horses on a water treadmill :effect of speed and water height on oxygen consumption and cardiorespiratory parameters. BMC Veterinary Research. 2017; 13: 360-369.

15. Sukenik S, Abu-Shakra M, Flusser D. Balneotherapy in autoimmune diseases. Isr J Med Sci. 1997; 33(4): 25861.

16. Yamaoka K, Mitsunobu F, Hanamoto K, Shibuya K, Mori S. et al. Biochemical comparison between radon effects and thermal effects on humans in radon hot spring therapy. J Radiat Res. 2004; 45(1): 83-8.

17. Wang HJ, Gao B, Zakhari S, Nagy LE. Inflammation in alcoholic liver disease. Annu Rev Nutr. 2012; 32:34368.

18. Gao B, Tsukamoto H. Inflammation in Alcoholic and Nonalcoholic Fatty Liver Disease: Friend or Foe? Gastroenterology. 2016; 150(8): 1704-9.
19. Szabo S, Trier JS, Brown A, Schnoor J. Early vascular injury and increased vascular permeability in gastric mucosal injury caused by ethanol in the rat. Gastroenterology. 1985; 88:228-36.

20. Tarner IH, Muller-Ladner U, Uhlemann C, Lange U. The effect of mild whole-body hyperthermia on systemic levels of TNF-alpha, IL-1 beta, and IL-6 in patients with ankylosingspondylitis. Clin Rheumatol. 2009; 28(4): 397 402.

21. Pereira CD, Severo M, Araújo JR, Guımarães JT, Pestana D. et al. Relevance of a hypersaline sodium-rich naturally sparkling mineral water to the protection against Metabolic Syndrome induction in fructose-fed Sprague-Dawley rats: a biochemical, metabolic and redox approach. Int $\mathrm{J}$ Endocrinol. 2014: 384583 .

22. Perez-Granados AM, Navas-Carretero S, Schoppen S, Vaquero MP. Reduction in cardiovascular risk by sodium-bicarbonated mineral water in moderately hypercholesterolemic young adults. J Nutr Biochem. 2010; 21: 948-953.

23. Schoppen S, Pérez-Granados AM, Carbajal A, Oubiña P, Sánchezmuniz FJ, et al A sodium-rich carbonated mineral water reduces cardiovascular risk in postmenopausal women. J Nutr. 2004; 134(5): 1058-63.

24. Vaganova VS, Knyshova VV. Effect of complex treatment of chronic gastritis with carbonated magnesium-calcium mineral water on lipid homeostasis. Vopr Kurortol Fizioter Lech Fiz Kult. 2003; (2):32-5.

25. Fioravanti A, Adamczyk P, Pascarelli NA, Giannitti C, Urso R., et al. Clinical and biochemical effects of a 3week program of diet combined with spa therapy in obese and diabetic patients: a pilot open study. Int $\mathrm{J}$ Biometeorol. 2015; 59(7):783-9.

26. Diamond MP, Chauhan S, Kruger M, Subramanıan M. Values of fasting glucose levels, glucose tolerance tests, and glucose-insulin ratios as predictors of glucose tolerance. Fertil Steril. 2003; 80(4): 1022-5.

27. Scheiner B, Lindner G, Reiberger T. Acid-base disorders in liver disease. J Hepatol, 2017; 67:10621073.

28. Hashimoto M., Yamomoto N. Decrease in heart rate by artificial $\mathrm{CO}^{2}$ hot spring bathing is inhibited by $\beta 1$-adrenoceptor blockade in anesthesied rats. $\mathrm{J}$ Appl Physiol. 2004; 96: 226-232.

29. Xu L, Wu L, Liu T, Xing W, Cao X et al. Effect of a 21-day balneotherapy program on blood cell counts, ponogen levels, and blood biochemical indexes in servicemen in sub-health condition. Journal of physical therapy science. 2017; 29(9):1573-1577

30. Bienia A, Sodolskiw, Luchowska E. The effect of chronic alcohol abuse on gastric and duodenal mucosa. Ann Univ Mariae Curie Sklodowska Med. 2002; 57(2):570-82. 

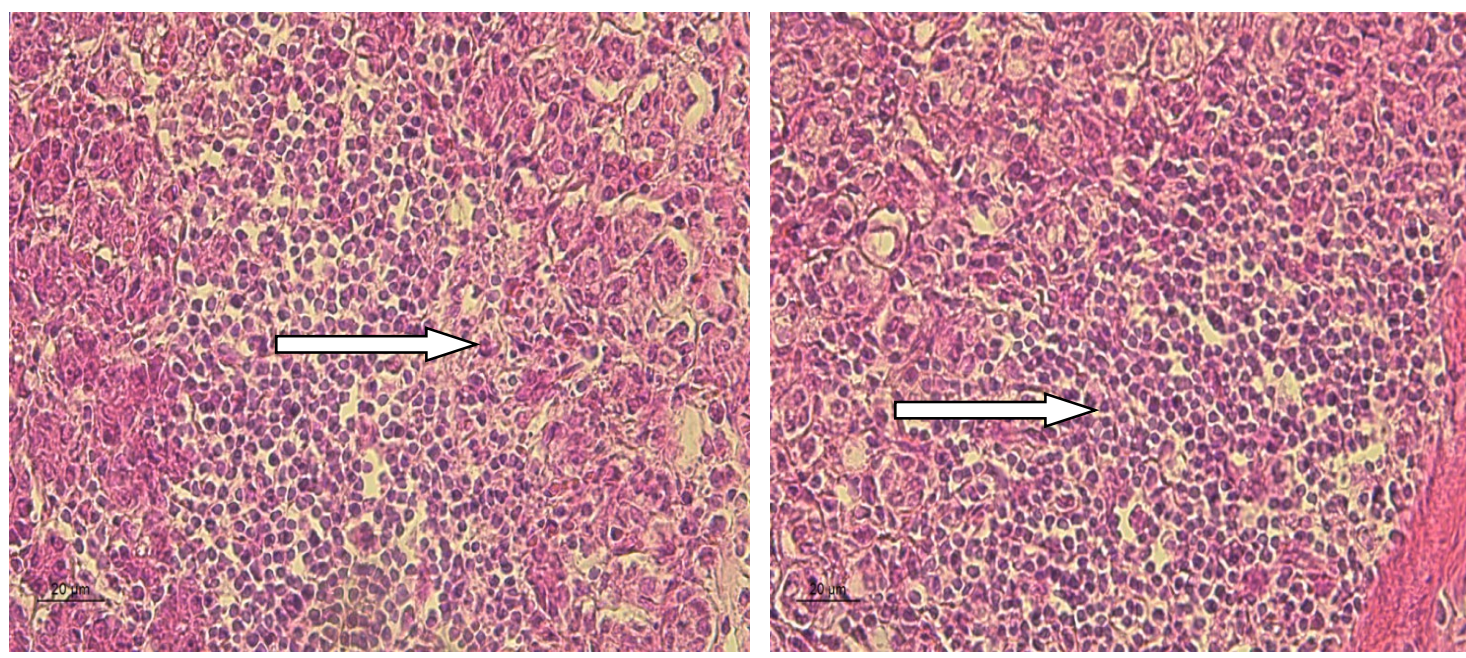

Figure 1. 10x40 HXE Staining. Stomach. Severe inflammatory picture characterized by mononuclear cell infiltrations.

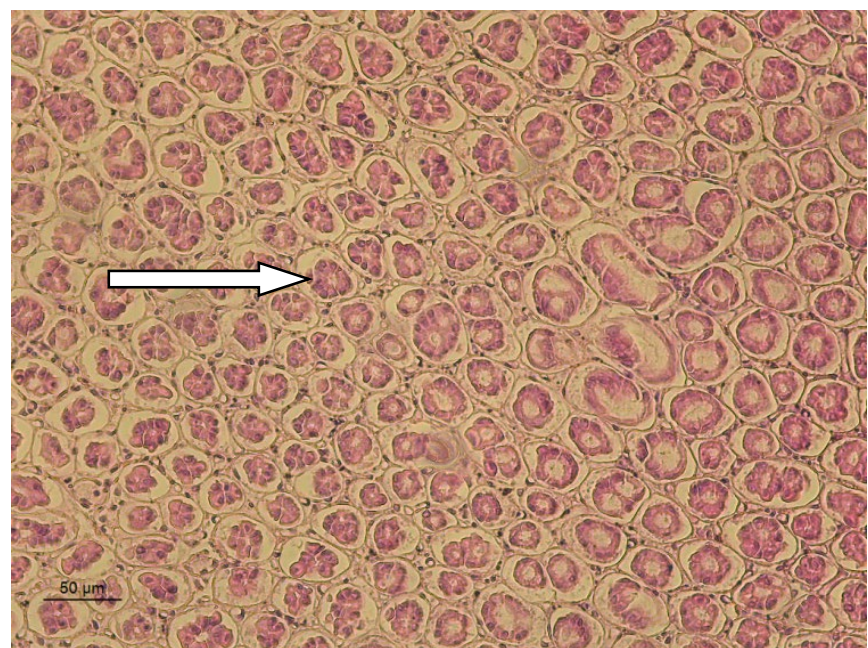

Figure 2. 10x20 HXE Staining. Stomach. Restoration of the tissue integrity and its normal state (Day 21. Study group).

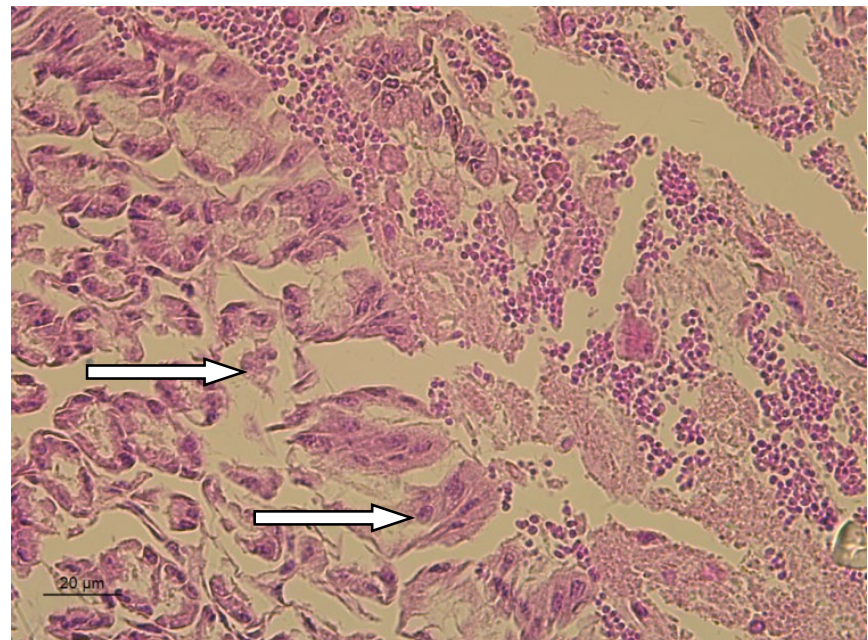

Figure 3. 10x40 HXE Staining. Stomach. tissue integrity not achieved, inflammation characterized by mononuclear cell infiltration (Day 21. Control group). 
Table 1. Statistical comparison of body temperature, pulse and respiratory in the animals

\begin{tabular}{|c|c|c|c|c|}
\hline \multirow{2}{*}{\multicolumn{2}{|c|}{ Measurement Time/Parameters }} & \multirow{3}{*}{$\begin{array}{l}T \\
\left({ }^{\circ} \mathrm{C}\right) \\
X \pm S D \\
\end{array}$} & \multirow{3}{*}{$\begin{array}{l}P \\
\text { (frequence/min) } \\
X \pm S D\end{array}$} & \multirow{3}{*}{$\begin{array}{l}R \\
\text { (frequence/min) } \\
X \pm S D\end{array}$} \\
\hline & & & & \\
\hline & Groups & & & \\
\hline BS $(n=40)$ & - & $37.10 \pm 0.10$ & $334.12 \pm 38.43^{d}$ & $117.13 \pm 25.30^{d}$ \\
\hline AFG $(n=36)$ & - & $37.20 \pm 0.10$ & $310.26 \pm 44.15^{\mathrm{e}}$ & $106.13 \pm 44.10^{\mathrm{e}}$ \\
\hline \multirow{2}{*}{$\begin{array}{l}\text { AT } \\
\text { 1st Day }\end{array}$} & CG $(n=16)$ & $37.20 \pm 0.20$ & $311.18 \pm 38.37^{\mathrm{e}}$ & $108.20 \pm 32.40^{\mathrm{e}}$ \\
\hline & SG $(n=16)$ & $37.10 \pm 0.10$ & $349.16 \pm 37.18^{\mathrm{cd}}$ & $137.12 \pm 30.20^{c}$ \\
\hline \multirow{2}{*}{$\begin{array}{l}\text { AT } \\
\text { 7th Day }\end{array}$} & CG $(n=12)$ & $37.30 \pm 0.20$ & $325.24 \pm 32.20^{d}$ & $114.16 \pm 20.18^{d}$ \\
\hline & SG $(n=12)$ & $37.20 \pm 0.10$ & $368.32 \pm 32.17^{c}$ & $148.30 \pm 22.14^{b}$ \\
\hline \multirow{2}{*}{$\begin{array}{l}\text { AT } \\
\text { 14th Day }\end{array}$} & $C G(n=8)$ & $37.10 \pm 0.10$ & $328.56 \pm 23.44^{d}$ & $115.28 \pm 16.00^{d}$ \\
\hline & SG $(n=8)$ & $37.20 \pm 0.20$ & $465.28 \pm 21.40^{b}$ & $162.27 \pm 15.20^{\mathrm{a}}$ \\
\hline \multirow{2}{*}{$\begin{array}{l}\text { AT } \\
\text { 21th Day }\end{array}$} & CG $(n=4)$ & $37.10 \pm 0.10$ & $327.15 \pm 9.12^{c}$ & $117.45 \pm 6.12^{d}$ \\
\hline & SG $(n=4)$ & $37.20 \pm 0.10$ & $497.46 \pm 8.50^{\mathrm{a}}$ & $166.18 \pm 7.20^{\mathrm{a}}$ \\
\hline
\end{tabular}

a-e : Different letters in the same column are statistically significant $(\mathrm{p}<0.05)$. BS: Before study, AGF: After gastritis formation, AT: After treatment, CG: Control group, SG: Study group

Table 2. Hematological findings.

\begin{tabular}{|c|c|c|c|c|c|c|c|}
\hline \multicolumn{2}{|c|}{$\begin{array}{l}\text { Measurement } \\
\text { Time/Parameters }\end{array}$} & \multirow{2}{*}{$\begin{array}{l}\text { WBC } \\
\left(10^{3} / \mathrm{mm} 3\right) \\
\mathrm{X} \pm \mathrm{SD}\end{array}$} & \multirow{2}{*}{\begin{tabular}{|l|}
$\begin{array}{l}\text { RBC } \\
\left(10^{6} / \mathrm{mm} 3\right)\end{array}$ \\
$\mathrm{X} \pm \mathrm{SD}$
\end{tabular}} & \multirow{2}{*}{\begin{tabular}{|l|}
$\begin{array}{l}\text { HB } \\
(\mathrm{g} / \mathrm{dl})\end{array}$ \\
$\mathbf{X} \pm \mathrm{SD}$ \\
\end{tabular}} & \multirow{2}{*}{$\begin{array}{l}\begin{array}{l}\text { HCT } \\
(\%)\end{array} \\
\mathrm{X} \pm \mathrm{SD}\end{array}$} & \multirow{2}{*}{\begin{tabular}{|l|}
$\begin{array}{l}\text { PLT } \\
\left(10^{3} / \mathrm{mm} 3\right)\end{array}$ \\
$\mathrm{X} \pm \mathrm{SD}$
\end{tabular}} & \multirow{2}{*}{$\begin{array}{l}\begin{array}{l}\text { MCV } \\
\text { (fl) }\end{array} \\
\mathrm{X} \pm \text { SD } \\
\end{array}$} \\
\hline & Groups & & & & & & \\
\hline Di: & & $8.48 \pm 2.13^{\mathrm{f}}$ & $786+203 a$ & $14.02 \pm 2.18^{\mathrm{a}}$ & $44.16 \pm 3.14^{\mathrm{a}}$ & $292.80 \pm 56.22^{\mathrm{a}}$ & $56.29 \pm 0.48^{\mathrm{g}}$ \\
\hline $\mathbf{A F G}(\mathrm{n}=36)$ & - & $1.18^{\mathrm{a}}$ & $3^{\mathrm{d}}$ & $7.68 \pm 2.16^{\mathrm{e}}$ & $34.28 \pm 4.40^{\mathrm{f}}$ & $\pm 48.45^{\mathrm{e}}$ & $6.23^{\mathrm{a}}$ \\
\hline \multirow{2}{*}{$\begin{array}{l}\text { AT } \\
\text { 1st Day }\end{array}$} & & & & & & & \\
\hline & & & & 8.08 & $3.34^{\mathrm{e}}$ & $13^{\mathrm{de}}$ & 4.22 \\
\hline \multirow{2}{*}{$\begin{array}{l}\text { AT } \\
\text { 7th Day }\end{array}$} & & & & & 34. & & 74 . \\
\hline & & & & & & & 66.3 \\
\hline \multirow{2}{*}{$\begin{array}{l}\text { AT } \\
\text { 14th Day }\end{array}$} & $\mathrm{CG}$ & $15.56 \pm 2.28^{\mathrm{b}}$ & $4.96 \pm 0.67^{\mathrm{d}}$ & $8.23 \pm 0.66^{\mathrm{d}}$ & $36.48 \pm 1.57^{\mathrm{d}}$ & \begin{tabular}{|l}
$197.13 \pm 25.43^{\mathrm{de}}$ \\
\end{tabular} & $73.37 \pm 1.40^{\mathrm{d}}$ \\
\hline & & & & & & & of \\
\hline \multirow{2}{*}{$\begin{array}{l}\text { AT } \\
\text { 21th Day }\end{array}$} & $\mathrm{CG}$ & $13.48 \pm 0.62^{\mathrm{d}}$ & $5.69 \pm 0.38^{c}$ & $9.65 \pm 0.38^{c}$ & $38.28 \pm 0.56^{\mathrm{d}}$ & $202.18 \pm 12.24^{\mathrm{d}}$ & $67.48 \pm 0.68^{\mathrm{d}}$ \\
\hline & SG $(n=4)$ & $8.44 \pm 0.56^{\mathrm{f}}$ & $8.03 \pm 0.32^{\mathrm{a}}$ & $13.88 \pm 0.34^{\mathrm{a}}$ & $44.16 \pm 0.47^{\mathrm{a}}$ & $286.32 \pm 13.42^{\mathrm{a}}$ & $55.02 \pm 0.44^{\mathrm{g}}$ \\
\hline
\end{tabular}

a-g: Different letters in the same column are statistically significant $(\mathrm{p}<0.05)$. BS: Before study, AGF: After gastritis

\begin{tabular}{|c|c|c|c|c|c|c|c|c|}
\hline \multicolumn{2}{|c|}{$\begin{array}{l}\text { Measurement } \\
\text { Time/Parameters }\end{array}$} & \multirow{2}{*}{$\begin{array}{l}\begin{array}{l}\text { MCH } \\
\text { (pg) }\end{array} \\
\mathrm{X} \pm \mathrm{SD}\end{array}$} & \multirow{2}{*}{\begin{tabular}{|l|}
$\begin{array}{l}\text { MCHC } \\
(\mathbf{g} / \mathbf{d l})\end{array}$ \\
$\mathrm{X} \pm \mathrm{SD}$ \\
\end{tabular}} & \multirow{2}{*}{$\begin{array}{l}\text { LENF } \\
\% \\
\mathbf{X} \pm \text { SD }\end{array}$} & \multirow{2}{*}{\begin{tabular}{|l|l}
$\begin{array}{l}\text { NOTR } \\
\%\end{array}$ \\
$\mathrm{X} \pm$ SD \\
\end{tabular}} & \multirow{2}{*}{\begin{tabular}{|l|}
$\begin{array}{l}\text { EOS } \\
\%\end{array}$ \\
$\mathrm{X} \pm$ SD \\
\end{tabular}} & \multirow{2}{*}{$\begin{array}{l}\text { MON } \\
\% \\
\mathrm{X} \pm \mathrm{SD}\end{array}$} & \multirow{2}{*}{$\begin{array}{l}\text { BAS } \\
\% \\
\mathbf{X} \pm \text { SD }\end{array}$} \\
\hline & Groups & & & & & & & \\
\hline & - & $17.78 \pm 2.14^{\mathrm{a}}$ & $31.76 \pm 2.43^{\mathrm{a}}$ & $63.17 \pm 7.18^{\mathrm{a}}$ & $32.80 \pm 2.30^{\mathrm{f}}$ & $2.40 \pm 0.50^{\text {cd }}$ & $3.43 \pm 1.20^{\mathrm{f}}$ & ÖD \\
\hline $\mathbf{A F G}$ & - & $1776+314 a$ & & $4.38 \pm 6.16^{g}$ & & $3.30 \pm 0.50^{\mathrm{a}}$ & & \\
\hline \multirow{2}{*}{$\begin{array}{l}\text { AT } \\
\text { 1st Day }\end{array}$} & $\mathrm{CC}$ & & & $6^{\mathrm{g}}$ & $2^{\mathrm{a}^{\mathrm{a}}}$ & & $12^{\mathrm{b}}$ & $\mathrm{D}$ \\
\hline & & 16.3 & 22. & $18^{\mathrm{f}}$ & $0^{\mathrm{b}}$ & & $4^{\mathrm{c}}$ & (Öم \\
\hline \multirow{2}{*}{$\begin{array}{l}\text { AT } \\
\text { 7th Day }\end{array}$} & $\mathrm{CG}$ & 16.72 & 23.22 & $48.56 \pm 3.47^{\mathrm{e}}$ & $.10^{\mathrm{ab}}$ & $40^{\mathrm{ab}}$ & $1.18^{\mathrm{bc}}$ & ÖD \\
\hline & & 17.3 & & 54.2 & & & & Öم \\
\hline \multirow{2}{*}{$\begin{array}{l}\text { AT } \\
\text { 14th Day }\end{array}$} & $\mathrm{CG}$ & 17.76 & 25.6 & $52.34 \pm 2.24^{e}$ & $40^{\mathrm{bc}}$ & 2.80 & $5.18 \pm 0.50^{c}$ & ÖD \\
\hline & SG (n & $17.75 \pm 0.57^{\mathrm{a}}$ & $27.63 \pm 0.54^{\mathrm{b}}$ & $58.20 \pm 1.45^{\mathrm{b}}$ & 37.02 & $2.20 \pm 0.20^{\mathrm{c}}$ & $4.08 \pm 0.40^{\mathrm{e}}$ & ÖD \\
\hline \multirow{2}{*}{$\begin{array}{l}\text { AT } \\
\text { 21th Day }\end{array}$} & & $0.34^{\mathrm{oc}}$ & 0.28 & $56.27 \pm 0.45^{\mathrm{c}}$ & $.50^{\mathrm{d}}$ & & $0.50^{\mathrm{d}}$ & \\
\hline & $\mathrm{S}$ & $17.23 \pm 0.25^{\mathrm{a}}$ & $31.54 \pm 0.35^{\mathrm{a}}$ & $05 \pm 0.38^{\mathrm{a}}$ & $33.01 \pm 0.40^{\mathrm{f}}$ & $2.00 \pm 0.10^{\mathrm{d}}$ & $3.40 \pm 0.40^{\mathrm{f}}$ & ÖD \\
\hline
\end{tabular}

formation, AT: After treatment, CG: Control group, SG: Study group 
Table 3. Blood Biochemical Findings.

\begin{tabular}{|c|c|c|c|c|c|c|}
\hline \multicolumn{2}{|c|}{$\begin{array}{l}\text { Measurement } \\
\text { Time/Parameters }\end{array}$} & \multirow{2}{*}{$\begin{array}{l}\begin{array}{l}\text { AST } \\
\text { (IU/L) }\end{array} \\
\mathrm{X} \pm \text { SD }\end{array}$} & \multirow{2}{*}{$\begin{array}{l}\text { ALT } \\
\text { (IU/L) } \\
\mathrm{X} \pm \text { SD }\end{array}$} & \multirow{2}{*}{$\begin{array}{l}\text { CK } \\
\text { (IU/L) } \\
X \pm \text { SD }\end{array}$} & \multirow{2}{*}{\begin{tabular}{|l}
$\begin{array}{l}\text { ALP } \\
\text { (IU/L) }\end{array}$ \\
$X \pm S D$ \\
\end{tabular}} & \multirow{2}{*}{\begin{tabular}{|l|}
$\begin{array}{l}\text { LDH } \\
\text { (IU/L) }\end{array}$ \\
$\mathbf{X} \pm$ SD \\
\end{tabular}} \\
\hline & Groups & & & & & \\
\hline BS $(n=40)$ & - & $97.79 \pm 13.18^{\mathrm{g}}$ & $56.54 \pm 5.44^{1}$ & $204.53 \pm 37.16^{\mathrm{e}}$ & $79.33 \pm 8.45^{\mathrm{e}}$ & $265.36 \pm 44.14^{\mathrm{d}}$ \\
\hline AFG $(n=36)$ & - & $260.18 \pm 34.48^{\mathrm{ab}}$ & $176.32 \pm 34.12^{\mathrm{a}}$ & $312.23 \pm 54.12^{\mathrm{a}}$ & $154.28 \pm 32.21^{\mathrm{a}}$ & $332.34 \pm 56.43^{\mathrm{a}}$ \\
\hline \multirow{2}{*}{$\begin{array}{l}\text { AT } \\
\text { 1st Day }\end{array}$} & CG $(n=16)$ & $272.14 \pm 44.32^{\mathrm{a}}$ & $175.28 \pm 33.42^{\mathrm{a}}$ & $310.48 \pm 49.13^{\mathrm{a}}$ & $153.27 \pm 29.45^{\mathrm{a}}$ & $333.39 \pm 62.24^{\mathrm{a}}$ \\
\hline & SG $(n=16)$ & $251.12 \pm 37.25^{b}$ & $165.08 \pm 31.14^{\mathrm{ab}}$ & $292.24 \pm 43.21^{\mathrm{ab}}$ & $150.13 \pm 26.37^{\mathrm{a}}$ & $329.13 \pm 54.43^{\mathrm{a}}$ \\
\hline \multirow{2}{*}{$\begin{array}{l}\text { AT } \\
\text { 7th Day }\end{array}$} & $\mathrm{CG}(\mathrm{n}=12)$ & $252.43 \pm 32.12^{\mathrm{b}}$ & $162.37 \pm 28.23^{\mathrm{ab}}$ & $287.28 \pm 32.14^{\mathrm{b}}$ & $148.22 \pm 18.31^{\mathrm{a}}$ & $327.28 \pm 37.16^{\mathrm{a}}$ \\
\hline & SG (n=12) & $196.21 \pm 24.22^{\mathrm{e}}$ & $142.23 \pm 26.12^{\mathrm{e}}$ & $251.48 \pm 32.23^{\mathrm{c}}$ & $117.32 \pm 16.62$ & $302.21 \pm 28.23^{b}$ \\
\hline \multirow{2}{*}{$\begin{array}{l}\text { AT } \\
\text { 14th Day }\end{array}$} & $\mathrm{CG}(\mathrm{n}=8)$ & $213.05 \pm 17.44^{\mathrm{c}}$ & $155.17 \pm 17.34^{\mathrm{d}}$ & $268.22 \pm 13.04^{\mathrm{bc}}$ & $133.34 \pm 12.32^{b}$ & $302.13 \pm 23.44^{b}$ \\
\hline & $\mathrm{SG}(\mathrm{n}=8)$ & $163.45 \pm 12.13^{\mathrm{f}}$ & $103.15 \pm 12.23^{\mathrm{g}}$ & $217.23 \pm 10.33$ & $96.88 \pm 8.14^{d}$ & $284.22 \pm 12.14^{\mathrm{c}}$ \\
\hline \multirow{2}{*}{$\begin{array}{l}\text { AT } \\
\text { 21th Day }\end{array}$} & $\mathrm{CG}(\mathrm{n}=4)$ & $204.42 \pm 9.32^{\mathrm{d}}$ & $127.44 \pm 9.32^{\mathrm{f}}$ & $241.54 \pm 7.16^{\mathrm{d}}$ & $122.13 \pm 9.45^{\mathrm{c}}$ & $287.21 \pm 9.10^{\mathrm{c}}$ \\
\hline & $\mathrm{SG}(\mathrm{n}=4)$ & $101.06 \pm 7.24^{\mathrm{g}}$ & $68.12 \pm 7.34^{\mathrm{h}}$ & $202.23 \pm 6.42^{\mathrm{e}}$ & $75.35 \pm 6.13^{\mathrm{e}}$ & $264.05 \pm 7.23^{\mathrm{d}}$ \\
\hline
\end{tabular}

\begin{tabular}{|c|c|c|c|c|c|c|c|}
\hline \multicolumn{2}{|c|}{$\begin{array}{l}\text { Measurement } \\
\text { Time/Parameters }\end{array}$} & \multirow{2}{*}{$\begin{array}{l}\text { TP } \\
\text { (g/dl) } \\
X \pm S D\end{array}$} & \multirow{2}{*}{$\begin{array}{l}\begin{array}{l}\text { ALB } \\
(\mathrm{g} / \mathrm{dl})\end{array} \\
\mathrm{X} \pm \mathrm{SD}\end{array}$} & \multirow{2}{*}{\begin{tabular}{|l|}
$\mathbf{G L U}$ \\
(g/dl)
\end{tabular}} & \multirow{2}{*}{$\begin{array}{l}\text { CREA } \\
\text { (mg/dl) }\end{array}$} & \multirow{2}{*}{$\begin{array}{l}\text { UREA } \\
\text { (mg/dl) }\end{array}$} & \multirow{2}{*}{\begin{tabular}{|l}
$\begin{array}{l}\mathbf{I g G} \\
(\mathrm{mg} / \mathrm{ml})\end{array}$ \\
$\mathbf{X} \pm \mathbf{S D}$ \\
\end{tabular}} \\
\hline & Groups & & & & & & \\
\hline BS $(n=40)$ & - & $57.28 \pm 5.43^{\mathrm{a}}$ & $34.25 \pm 1.34^{\mathrm{a}}$ & $156.67 \pm 12.43^{\mathrm{a}}$ & $0.60 \pm 0.03^{\mathrm{de}}$ & $8.83 \pm 2.15^{\mathrm{d}}$ & $3.19 \pm 1.36^{\mathrm{e}}$ \\
\hline AFG $(n=36)$ & - & $34.05 \pm 4.23^{\mathrm{f}}$ & $21.00 \pm 2.32^{\mathrm{f}}$ & $118.97 \pm 9.13^{\text {ef }}$ & $1.43 \pm 0.53^{\mathrm{a}}$ & $12.23 \pm 3.13^{\mathrm{a}}$ & $6.36 \pm 2.28^{\mathrm{a}}$ \\
\hline \multirow{2}{*}{$\begin{array}{l}\text { AT } \\
\text { 1st Day }\end{array}$} & CG $(n=16)$ & $34.25 \pm 5.13^{\mathrm{f}}$ & $21.38 \pm 2.23^{\mathrm{ef}}$ & $117.23 \pm 7.12^{\mathrm{f}}$ & $1.30 \pm 1.13^{\mathrm{ab}}$ & $12.38 \pm 3.32^{\mathrm{a}}$ & $6.42 \pm 2.23^{\mathrm{a}}$ \\
\hline & SG (n=16) & $35.44 \pm 5.14^{\mathrm{ef}}$ & $21.49 \pm 2.18^{\mathrm{ef}}$ & $119.21 \pm 6.07^{\mathrm{e}}$ & $1.12 \pm 1.03^{\mathrm{b}}$ & $12.02 \pm 3.16^{\mathrm{a}}$ & $6.02 \pm 2.14^{\mathrm{ab}}$ \\
\hline \multirow{2}{*}{$\begin{array}{l}\text { AT } \\
\text { 7th Day }\end{array}$} & CG (n=12) & $36.24 \pm 3.11^{\mathrm{e}}$ & $22.25 \pm 1.54^{\mathrm{e}}$ & $119.03 \pm 4.27^{\mathrm{e}}$ & $1.14 \pm 0.56^{\mathrm{b}}$ & $11.14 \pm 1.21^{\mathrm{b}}$ & $5.65 \pm 1.67^{\mathrm{b}}$ \\
\hline & SG $(n=12)$ & $41.14 \pm 2.23^{\mathrm{cd}}$ & $27.28 \pm 1.38^{\mathrm{c}}$ & $136.48 \pm 3.34^{\mathrm{d}}$ & $0.81 \pm 0.45^{\mathrm{c}}$ & $9.03 \pm 0.43^{\mathrm{c}}$ & $4.05 \pm 0.54^{\mathrm{c}}$ \\
\hline \multirow{2}{*}{$\begin{array}{l}\text { AT } \\
\text { 14th Day }\end{array}$} & $\mathrm{CG}(\mathrm{n}=8)$ & $40.45 \pm 2.34^{\mathrm{d}}$ & $25.13 \pm 1.15^{\mathrm{d}}$ & $139.05 \pm 2.54^{\mathrm{cd}}$ & $1.10 \pm 0.32^{b}$ & $10.27 \pm 0.64^{\mathrm{bc}}$ & $4.86 \pm 0.63^{\mathrm{bc}}$ \\
\hline & SG $(n=8)$ & $48.35 \pm 1.25^{\mathrm{b}}$ & $32.43 \pm 1.06^{\mathrm{b}}$ & $151.21 \pm 1.24^{\mathrm{b}}$ & $0.66 \pm 0.24^{\mathrm{d}}$ & $8.43 \pm 0.32^{\mathrm{d}}$ & $3.18 \pm 0.47^{\mathrm{e}}$ \\
\hline \multirow{2}{*}{$\begin{array}{l}\text { AT } \\
\text { 21th Day }\end{array}$} & $\mathrm{CG}(\mathrm{n}=4)$ & $43.03 \pm 0.28^{c}$ & $27.22 \pm 0.55^{\mathrm{c}}$ & $144.08 \pm 0.36^{\mathrm{c}}$ & $0.83 \pm 0.21^{\mathrm{c}}$ & $9.32 \pm 0.30^{\mathrm{bc}}$ & $4.12 \pm 0.38^{\mathrm{d}}$ \\
\hline & $\mathrm{SG}(\mathrm{n}=4)$ & $57.02 \pm 0.26^{\mathrm{a}}$ & $35.03 \pm 0.38^{\mathrm{a}}$ & $157.04 \pm 0.29^{\mathrm{a}}$ & $0.52 \pm 0.13^{\mathrm{e}}$ & $8.13 \pm 0.21^{\mathrm{d}}$ & $3.10 \pm 0.17^{\mathrm{e}}$ \\
\hline
\end{tabular}

a-1: Different letters in the same column are statistically significant $(\mathrm{p}<0.05)$. BS: Before study, AGF: After gastritis formation, AT: After treatment, CG: Control group, SG: Study group Table 4. Blood Gases Findings

\begin{tabular}{|c|c|c|c|c|c|c|c|c|c|c|c|}
\hline \multicolumn{2}{|c|}{$\begin{array}{l}\text { Measurement } \\
\text { Time/Parameters }\end{array}$} & \multirow{2}{*}{$\begin{array}{l}\mathrm{pH} \\
\mathrm{X} \pm \mathrm{SD} \\
\end{array}$} & \multirow{2}{*}{$\begin{array}{l}\begin{array}{l}\text { pCO2 } \\
(\mathrm{mmHg})\end{array} \\
\mathbf{X} \pm \mathbf{S D}\end{array}$} & \multirow{2}{*}{$\begin{array}{l}\text { HCO3- } \\
(\mathrm{mmol} / \mathrm{L}) \\
\mathrm{X} \pm \mathrm{SD}\end{array}$} & \multirow{2}{*}{$\begin{array}{l}\mathbf{B E} \\
(\mathrm{mEq} / \mathrm{L}) \\
\mathbf{X} \mathbf{S} \mathbf{D}\end{array}$} & \multirow{2}{*}{$\begin{array}{l}\text { TCO2 } \\
(\mathrm{mmol} / \mathrm{L}) \\
\mathrm{X} \pm \mathrm{SD}\end{array}$} & \multirow{2}{*}{$\begin{array}{l}\text { LACT } \\
(\mathrm{mmol} / \mathrm{L}) \\
\mathbf{X} \pm \mathrm{SD}\end{array}$} & \multirow{2}{*}{$\begin{array}{l}\mathrm{K}+ \\
(\mathrm{mmol} / \mathrm{L}) \\
\mathrm{X} \pm \mathrm{SD}\end{array}$} & \multirow{2}{*}{$\begin{array}{l}\mathrm{Na}+ \\
(\mathrm{mmol} / \mathrm{L})\end{array}$} & \multirow{2}{*}{$\begin{array}{l}\mathrm{Cl}- \\
(\mathrm{mmol} / \mathrm{L})\end{array}$} & \multirow{2}{*}{$\begin{array}{l}\mathrm{Ca}++ \\
\text { (mmol/L) } \\
\mathbf{X} \pm \mathrm{SD}\end{array}$} \\
\hline & Groups & & & & & & & & & & \\
\hline BS $(n=40)$ & - & $7.34 \pm 0.03^{\mathrm{ab}}$ & $43.34 \pm 0.28^{a}$ & $22.06 \pm 0.47^{c}$ & $-2.50 \pm 0.03^{c}$ & $23.28 \pm 0.34^{c}$ & $4.48 \pm 0.65^{c d}$ & $8.54 \pm 1.23^{\mathrm{a}}$ & $156.45 \pm 5.17^{e}$ & $116.38 \pm 3.46^{\text {ef }}$ & $11.02 \pm 2.14^{\mathrm{a}}$ \\
\hline $\begin{array}{l}\text { AFG } \\
(n=36)\end{array}$ & - & $7.23 \pm 0.04^{c}$ & $35.43 \pm 0.56^{\text {de }}$ & $14.40 \pm 0.31^{\mathrm{e}}$ & $-11.80 \pm .0 .02^{h}$ & $15.48 \pm 1.23^{f}$ & $5.47 \pm 0.68^{\mathrm{a}}$ & $6.48 . \pm 0.64^{c}$ & $238.16 \pm 13.41^{\mathrm{a}}$ & $201.35 \pm 4.43^{\mathrm{a}}$ & $7.15 \pm 2.15^{d}$ \\
\hline \multirow[t]{2}{*}{$\begin{array}{l}\text { AT } \\
\text { 1st Day }\end{array}$} & $\begin{array}{l}\text { CG } \\
(n=16)\end{array}$ & $7.23 \pm 0.04^{c}$ & $35.38 \pm 0.53^{\text {de }}$ & $14.38 \pm 0.34^{f}$ & $-11.72 \pm 0.03^{h}$ & $15.43 \pm 1.34^{f}$ & $5.53 \pm 0.47^{a}$ & $6.41 \pm 0.58^{c}$ & $237.27 \pm 14.05^{a}$ & $203.42 \pm 5.20^{\mathrm{a}}$ & $7.22 \pm 2.34^{d}$ \\
\hline & $\begin{array}{l}\text { SG } \\
(n=16)\end{array}$ & $7.26 \pm 0.03^{c}$ & $34.76 \pm 0.48^{e}$ & $15.10 \pm 0.22^{\text {ef }}$ & $-10.61 \pm .0 .02^{\mathrm{g}}$ & $16.15 \pm 1.13^{\text {ef }}$ & $5.23 \pm 0.44^{\mathrm{ab}}$ & $6.81 . \pm 0.47^{b c}$ & $223.15 \pm 13.02^{b}$ & $191.65 \pm 4.31^{b}$ & $7.56 \pm 2.32^{\mathrm{d}}$ \\
\hline \multirow[t]{2}{*}{$\begin{array}{l}\text { AT } \\
\text { 7th Day }\end{array}$} & $\begin{array}{l}\text { CG } \\
(n=12)\end{array}$ & $7.25 \pm 0.02^{c}$ & $36.03 \pm 0.38^{d}$ & $15.30 \pm 0.20^{\mathrm{ef}}$ & $-10.6 \pm 0.02^{g}$ & $16.40 \pm 1.24^{\text {ef }}$ & $5.21 \pm 0.33^{\mathrm{ab}}$ & $6.53 \pm 0.54^{d}$ & $232.18 \pm 8.45^{\mathrm{ab}}$ & $189.24 \pm 4.14^{b}$ & $7.98 \pm 1.54^{b}$ \\
\hline & $\begin{array}{l}\text { SG } \\
(n=12)\end{array}$ & $7.34 \pm 0.02^{\mathrm{ab}}$ & $37.28 \pm 0.27^{c}$ & $19.41 \pm 0.27^{c d}$ & $-5.51 \pm .0 .02^{d}$ & $20.53 \pm 0.68^{d}$ & $4.92 \pm 0.31^{\mathrm{c}}$ & $7.48 . \pm 0.45^{b}$ & $196.21 \pm 7.34^{d}$ & $142.23 \pm 3.07^{d}$ & $9.18 \pm 0.44^{b}$ \\
\hline \multirow[t]{2}{*}{$\begin{array}{l}\text { AT } \\
\text { 14th Day }\end{array}$} & $\begin{array}{l}\text { CG } \\
(n=8)\end{array}$ & $7.28 \pm 0.02^{d}$ & $37.18 \pm 0.43^{c d}$ & $16.91 \pm 0.30^{\mathrm{e}}$ & $-8.7 \pm 0.02^{f}$ & $18.02 \pm 0.43^{e}$ & $5.04 \pm 0.23^{b}$ & $6.89 \pm 0.37^{\mathrm{bc}}$ & $211.12 \pm 4.08^{c}$ & $168.02 \pm 2.41^{c}$ & $8.58 \pm 0.54^{c d}$ \\
\hline & $\begin{array}{l}\text { SG } \\
(n=8)\end{array}$ & $7.39 \pm 0.01^{\mathrm{a}}$ & $42.02 \pm 0.18^{b}$ & $24.60 \pm 0.23^{b}$ & $0.00 \pm .0 .00^{\mathrm{b}}$ & $25.83 \pm 0.27^{b}$ & $4.42 \pm 0.24^{c d}$ & $8.48 . \pm 0.33^{a}$ & $161.28 \pm 2.45^{e}$ & $121.06 \pm 0.63^{e}$ & $11.21 \pm 0.37^{a}$ \\
\hline \multirow[t]{2}{*}{$\begin{array}{l}\text { AT } \\
\text { 21th Day }\end{array}$} & $\begin{array}{l}\text { CG } \\
(n=4)\end{array}$ & $7.31 \pm 0.01^{b}$ & $38.54 \pm 0.32^{c}$ & $18.82 \pm 0.20^{d}$ & $-6.49 \pm 0.01^{e}$ & $19.94 \pm 0.23^{\mathrm{de}}$ & $4.83 \pm 0.17^{b c}$ & $7.43 \pm 0.25^{b}$ & $196.25 \pm 1.34^{d}$ & $140.12 \pm 0.54^{d}$ & $9.00 \pm 0.24^{b}$ \\
\hline & $\begin{array}{l}\text { SG } \\
(n=4)\end{array}$ & $7.41 \pm 0.01^{\mathrm{a}}$ & $44.03 \pm 0.12^{\mathrm{a}}$ & $27.03 \pm 0.10^{\mathrm{a}}$ & $2.51 \pm .0 .02^{\mathrm{a}}$ & $28.32 \pm 0.19^{a}$ & $4.23 \pm 0.15^{d}$ & $8.83 \pm 0.21^{\mathrm{a}}$ & $153.04 \pm 0.32^{\mathrm{e}}$ & $108.11 \pm 0.42^{f}$ & $11.38 \pm 0.16^{\mathrm{a}}$ \\
\hline
\end{tabular}

a-h: Different letters in the same column are statistically significant $(\mathrm{p}<0.05)$. BS: Before study, AGF: After gastritis formation, AT: After treatment, CG: Control group, SG: Study group 